\title{
Comparison of Cytotoxic activity and Interferon-g secretion by Natural Killer Cells in HIV-1 and HIV-2 infected individuals
}

\author{
Samuel Victor Nuvor ${ }^{1 *}$, Sarah Rowland-jones ${ }^{2}$, Hilton Whittle ${ }^{3}$, Assan Jaye ${ }^{3}$ \\ From $16^{\text {th }}$ International Symposium on HIV and Emerging Infectious Diseases \\ Marseille, France. 24-26 March 2010
}

\section{Background}

The role of NK cells in slowing disease progression in HIV-2 infected individuals compare to HIV-1 infected individuals.

\section{Methods}

In this study peripheral blood mononuclear cells were obtained from 30 HIV-1 and 30 HIV-2 infected subjects from each of 3 categories of CD4 T-cell counts $(>500$, 200-500 and $<200$ cells/ul) together with 50 HIV uninfected control subjects. Lytic activity and IFN-g secretion by NK cells from HIV-1 and HIV-2 infected subjects were measured by chromium-release and ELISPOT assays respectively following incubation of PBMC with the NK-sensitive K562 cells. Viral load was also measured from the plasma samples of the subjects.

\section{Results}

The cytotoxic response by NK cells was significantly higher in HIV-2 than in HIV-1 infection in subjects with CD4-T cell count $>500$ cell/ul $(\mathrm{p}<0.05)$ and was similar to that of the healthy controls. There was a significant correlation between the magnitude of the NK population and cytolytic activity in HIV-2 individuals $(\mathrm{r}=0.27$, $\mathrm{p}=0.01$ ). There was also an inverse relationship between the cytolytic activity and plasma viral load in HIV-2 infected subjects $(r=-0.27, p=0.009)$. Interferon-g secretion by NK cells in ELISPOT assays was similar in HIV-1 and HIV-2 infections at all categories of $\mathrm{CD}^{+} \mathrm{T}$ cell counts.

\footnotetext{
* Correspondence: vnuvor@yahoo.com

'University of Cape Coast, Cape Coast, Ghana
}

\section{Discussion}

The data suggest an efficient cytolytic function from NK cells in early HIV-2 infection, which is associated with high CD4 T cell counts. This may imply that a strategic immune-based therapy to control HIV disease through the enhancement of NK cell activity is worthy of consideration.

\section{Author details}

${ }^{1}$ University of Cape Coast, Cape Coast, Ghana. ${ }^{2}$ Wetherall Institute of Molecular Medicine, Oxford, UK. ${ }^{3}$ Medical Research Council, Banjul, Gambia.

Published: 11 May 2010

doi:10.1186/1742-4690-7-S1-P9

Cite this article as: Nuvor et al:: Comparison of Cytotoxic activity and Interferon-g secretion by Natural Killer Cells in HIV-1 and HIV-2 infected individuals. Retrovirology 2010 7(Suppl 1):P9.

Submit your next manuscript to BioMed Central and take full advantage of:

- Convenient online submission

- Thorough peer review

- No space constraints or color figure charges

- Immediate publication on acceptance

- Inclusion in PubMed, CAS, Scopus and Google Scholar

- Research which is freely available for redistribution 